\author{
І. С. Нікітенко, М. Л. Куцевол
}

Державний ВНЗ «Національний гірничий університет»

\title{
РЕЗУЛЬТАТИ МІНЕРАЛОГО-ПЕТРОГРАФІЧНОГО ДОСЛІДЖЕННЯ КОЛЕКЦІЇ СКІФСЬКОЇ КАМ'ЯНОЇ ПЛАСТИКИ 3 ДНІПРОПЕТРОВСЬКОГО НАЦІОНАЛЬНОГО ІСТОРИЧНОГО МУЗЕЮ ІМЕНІ Д. І. ЯВОРНИЦЬКОГО
}

\begin{abstract}
Визначено види гірських порід, що використовувались скіфським населенням Середнього Придніпров'я для виготовлення кам'яних скульптур. Зроблено висновки щодо особливостей застосування кам'яної сировини та вірогідних місць її розробки.

Ключові слова: кам'яна сировина, Середнє Придніпров'я, скіфська культура, кам'яна пластика, археологічна петрографія, стародавня гірнича справа.

Определены виды горных пород, использовавшиеся скифским населением Среднего Приднепровья для изготовления каменных скульптур. Сделаны выводы относительно особенностей применения каменного сырья и вероятных мест его разработки.

Ключевые слова: каменное сырье, Среднее Приднепровье, скифская культура, каменная пластика, археологическая петрография, древнее горное дело.
\end{abstract}

The types of rock that were used by the Scythian population of Transdnepria for stone sculpture production were determined. Conclusions were drawn about the raw stone materials used and the probable locations of their mining.

Key words: raw stone materials, Transdnepria, Scythian culture, plastic figures, archaeological petrography, ancient mining.

Вступ. Скіфська культура посідає дуже важливе місце у стародавній історії України. Вона панувала з VII до початку III ст. до н. е. і залишила велику кількість цінних археологічних пам'яток. Особливу увагу привертають витвори скіфської кам'яної пластики. Антропоморфні статуї, а також скульптурні зображення, виконані у звіриному стилі, є творами мистецтва, пов'язаними з віруваннями та звичаями цього народу.

3 точки зору розвитку стародавнього господарства, виготовлення кам'яних скульптур вимагало використання великих блоків гірських порід, котрі у більшості випадків могли бути отримані лише за допомогою певних гірничих прийомів. Таким чином, розвиток великої кам'яної пластики у скіфський час сприяв активізації гірничої справи та більшому використанню кам'яної сировини.

Витвори скіфської кам'яної пластики не настільки поширені, як кам'яні стели доби енеоліту-бронзи та половецькі статуї часів середньовіччя. Проте, в результаті археологічних розкопок, у музеях країни накопичено значну кількість даних витворів. Добре репрезентує скіфську монументальну скульптуру Середнього Придніпров'я колекція Дніпропетровського національного історичного музею ім. Д. І. Яворницького (ДНІМ). У ній знаходяться зразки кам'яної пластики 3 території всієї Дніпропетровської області, найбільше - 3 південного заходу, де розташовані найвизначніші скіфські курганні поховання.

Важливим питанням для археології та четвертинної геології є визначення походження сировини стародавніх кам'яних скульптур. Вирішувати подібні задачі дозволяє мінералого-петрографічний аналіз сировини артефактів. Дана стаття 
присвячена мінералого-петрографічному дослідженню творів скіфської кам'яної пластики 3 фондів ДНІМ. До сьогодні подібних аналізів скіфської скульптури 3 колекції музею не проводилося.

Мета і задачі. Метою дослідження було встановити найменування гірських порід, що використовувалися скіфським населенням Середнього Придніпров'я для виготовлення кам'яних скульптур, а також визначити можливі місця розробки кам'яної сировини.

Для виконання поставленої мети було необхідно провести мінералогопетрографічний аналіз сировини кам'яних стел та порівняти отримані дані 3 геологічною інформацією щодо розповсюдження певних видів гірських порід.

Виклад основного матеріалу. Для проведення дослідження нам було надано сім кам'яних артефактів з колекції ДНІМ, що походять з різних частин області (табл.). Шість із них було представлено антропоморфними статуями, один скульптурним зображенням, що, напевно, символізує голову лева. Макроскопічно сировина досліджених експонатів ідентифікувалася як гранітоїди і вапняки. В результаті проведення аналізів було встановлено точні найменування порід та їх мінералого-петрографічні характеристики.

Досліджені артефакти

Таблиия

\begin{tabular}{|c|c|c|c|c|c|}
\hline № & Найменування, розмір & $\begin{array}{c}\text { IHB. } \\
\text { № }\end{array}$ & Датування & Місце знахідки & Матеріал \\
\hline 1 & 2 & 3 & 4 & 5 & 6 \\
\hline 1 & $\begin{array}{l}\text { Статуя чоловіча: на довгій } \\
\text { пласкій плиті зображено } \\
\text { воїна, } h-225 \text { см }\end{array}$ & $\begin{array}{c}\text { A- } \\
7961\end{array}$ & $\begin{array}{l}\text { поч. VI - } \\
\text { IV ст. до } \\
\text { н. е. }\end{array}$ & $\begin{array}{l}\text { с. Любомирівка Кри- } \\
\text { ничанського р-ну }\end{array}$ & $\begin{array}{l}\text { Плагіограніт } \\
\text { окварцований } \\
\text { та } \\
\text { епідотизований }\end{array}$ \\
\hline 2 & $\begin{array}{l}\text { Статуя чоловіча: пласкій } \\
\text { плиті було надано контури } \\
\text { людської фігури, виділено } \\
\text { голову і плечі, } h-180 \text { cм }\end{array}$ & $\begin{array}{c}\text { A- } \\
7989\end{array}$ & $\begin{array}{l}\text { VI - IV ст. } \\
\text { до н. е. }\end{array}$ & $\begin{array}{l}\text { Можливо, околиці } \\
\text { м. Кривий Ріг }\end{array}$ & $\begin{array}{l}\text { Вапняк } \\
\text { оолітовий }\end{array}$ \\
\hline 3 & $\begin{array}{l}\text { Статуя чоловіча, } \\
10 \times 75 \times 110 \mathrm{~cm}\end{array}$ & $\begin{array}{c}\text { A- } \\
11418 \\
\end{array}$ & $\begin{array}{l}\text { V ст. до } \\
\text { н. е. }\end{array}$ & $\begin{array}{l}\text { с. Слов'янка Апос- } \\
\text { толівського р-ну }\end{array}$ & $\begin{array}{l}\text { Граніт } \\
\text { біотитовий }\end{array}$ \\
\hline 4 & $\begin{array}{l}\text { Статуя чоловіча: голова у } \\
\text { вигляді трапецієподібного } \\
\text { виступу, } h-115 \mathrm{~cm}\end{array}$ & $\begin{array}{c}\text { A- } \\
11717\end{array}$ & $\begin{array}{l}\text { V ст. до } \\
\text { н. е. }\end{array}$ & Томаківський р-н & $\begin{array}{l}\text { Граніт } \\
\text { біотитовий, } \\
\text { метасоматично } \\
\text { змінений } \\
\end{array}$ \\
\hline 5 & $\begin{array}{l}\text { Рельєфне зображення } \\
\text { голови лева (?), } \\
30 \times 24,5 \times 7,5 \text { cм }\end{array}$ & $\begin{array}{c}\mathrm{A}- \\
12541\end{array}$ & - & $\begin{array}{l}\text { с. Новокиївка } \\
\text { Томаківського p-ну }\end{array}$ & $\begin{array}{l}\text { Вапняк } \\
\text { органогенний }\end{array}$ \\
\hline 6 & $\begin{array}{l}\text { Статуя антропоморфна, } \\
92 \times 34 \times 20 \mathrm{~cm}\end{array}$ & $\begin{array}{c}\mathrm{A}- \\
12542 \\
\end{array}$ & $\begin{array}{l}\text { IV - III ст. } \\
\text { до н. е. }\end{array}$ & $\begin{array}{l}\text { с. Новокиївка } \\
\text { Томаківського p-ну }\end{array}$ & $\begin{array}{l}\text { Вапняк } \\
\text { органогенний }\end{array}$ \\
\hline 7 & $\begin{array}{l}\text { Статуя антропоморфна, } \\
165 \times 69 \times 14 \mathrm{~cm}\end{array}$ & $\begin{array}{c}\mathrm{A}- \\
13592 \\
\end{array}$ & $\begin{array}{l}\text { IV ст. } \\
\text { до н. е. }\end{array}$ & $\begin{array}{l}\text { с. Великоолександрівка } \\
\text { Васильківського р-ну }\end{array}$ & $\begin{array}{l}\text { Граніт } \\
\text { біотитовий }\end{array}$ \\
\hline
\end{tabular}

Статую із зображенням воӥна (A-7961) було виготовлено 3 сірого гранітоїду (рис. 1). 3 бічної сторони плити спостерігається слабовиражена гнейсоподібна текстура. За петрографічними особливостями, виявленими у шліфі, породу можна визначити як епідотизований та окварцований плагіограніт. Так, польові шпати (плагіоклаз та незначна частка мікрокліну) у шліфі складають $40 \%$, в той час, коли кварцу також міститься $40 \%$, а епідоту - $10 \%$ (рис. 2). Кварц утворює лінзоподібні мономінеральні прожилки. Виходячи з морфологічних ознак, мінерал утворився шляхом метасоматичного заміщення польових шпатів. Епідот 
розвинутий по мікрокліну й утворює дрібнозернисті агрегати. У породі присутня значна кількість слюд, більшість з яких представлена мусковітом і серицитом $9 \%$. Останній з них утворився за рахунок заміщення плагіоклазу. Біотиту міститься лише $1 \%$ від об'єму породи, по ньому розвинутий вторинний хлорит, представлений поодинокими лусками. Також фіксуються одиничні агрегати гетиту.

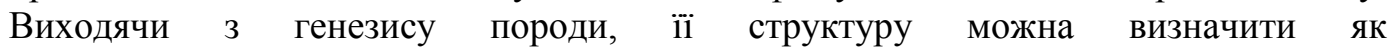
гетеролепідогранобластову.

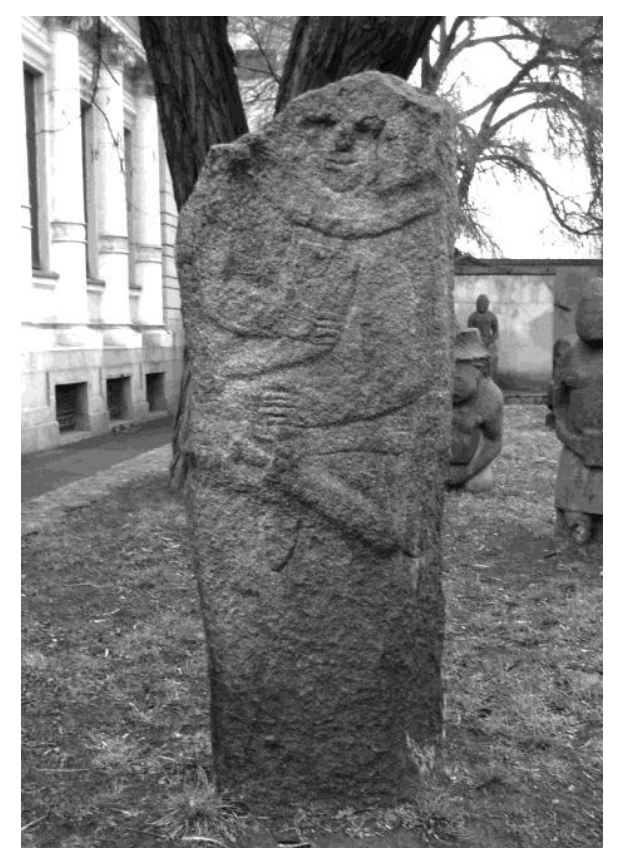

Рис. 1. Статуя із зображенням воїна (A-7961)

Походження. Гранітоїди досить поширені на території Середньопридніпровського мегаблоку Українського щита. Оскільки ми маємо справу 3 дуже зміненою породою, за петрографічними ознаками визначити іi походження досить проблематично. Найближчими до с. Любомирівка відслоненнями кристалічних порід $\epsilon$ прояви поблизу районного центру смт Кринички в долині p. Мокра Сура, а також родовища гранітів у долині p. Дніпро поблизу м. Дніпродзержинська [5]. Серед останніх слід відзначити Тритузнівське родовище, для порід якого характерні процеси епідотизації, зокрема, проявлені епідозити та різні епідотизовані породи [1]. Таким чином, найімовірнішим, на нашу думку, є походження сировини стели з долини Дніпра, хоча варіант іiі походження з долини р. Мокра Сура також виключати не можна. У будь-якому разі, за місцем видобутку сировину, з якої було виготовлено статую, можна визначити як місцеву. 


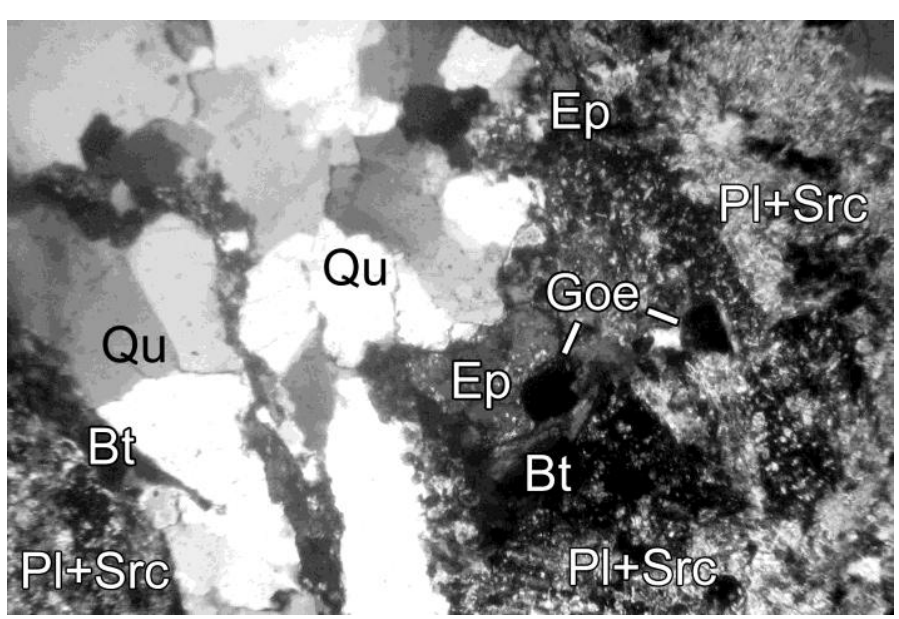

Рис. 2. Плагіограніт окварцований та епідотизований (А-7961).

Qu - кварц; PI+Src - плагіоклаз серицитизований; Ep - епідот; Bt - біотит; Goe - гетит.

Світло прохідне, з аналізатором, збільшення $47^{\mathrm{x}}$

Чоловічу статую (A-7989), що експонується у залі музею (рис. 3), було виготовлено з оолітового вапняку (рис. 4). Порода складена карбонатними оолітами концентричної будови. На контактах ооліти зцементовані мікрозернистим кальцитовим агрегатом. Центром кристалізації багатьох оолітів стали уламки кварцу та польових шпатів необкатаної форми. У центрі деяких оолітів та поза ними присутні рештки багатокамерних форамініфер. Порода містить дисперсну домішку гетиту. Пори поміж оолітами частіше не заповнені.

Походження. Місце знахідки статуї достеменно невідоме. Згідно з фондовими матеріалами, вона може походити 3 колекції О. М. Поля, створеної у другій половині XIX ст., а ймовірним районом походження стели $є$ Криворіжжя. Якщо спиратися на ці дані, то походження сировини статуї цілком може бути місцевим. Оолітові вапняки досить поширені на півдні Дніпропетровської області. Стратиграфічно вони належать до сарматських i понтичних відкладів [4]. Безпосередньо поблизу м. Кривий Ріг відмічаються три крупні родовища оолітових вапняків. Вони розташовані в районі смт Широке в долині р. Інгулець. Це Інгулецьке, Миколо-Козельське та Миколаївське родовища. Крім того, на півдні Кривбасу відомо про низку менших проявів зазначених порід [5]. 


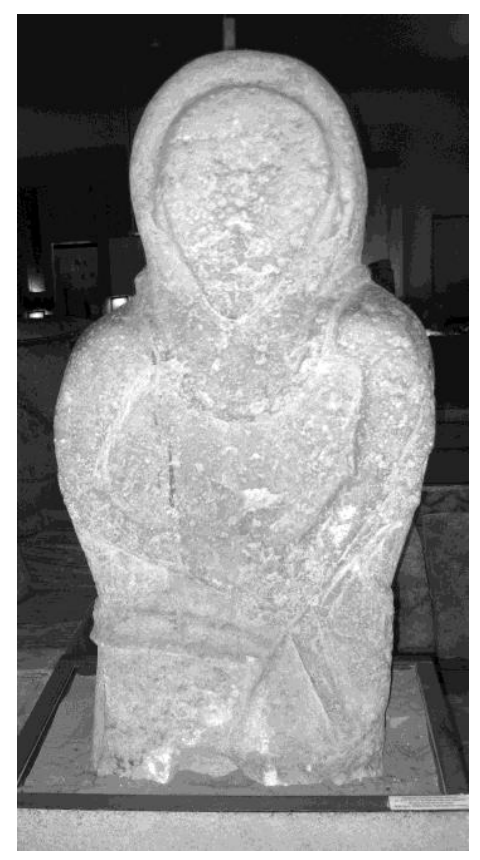

Рис. 3. Статуя чоловіча (А-7989)

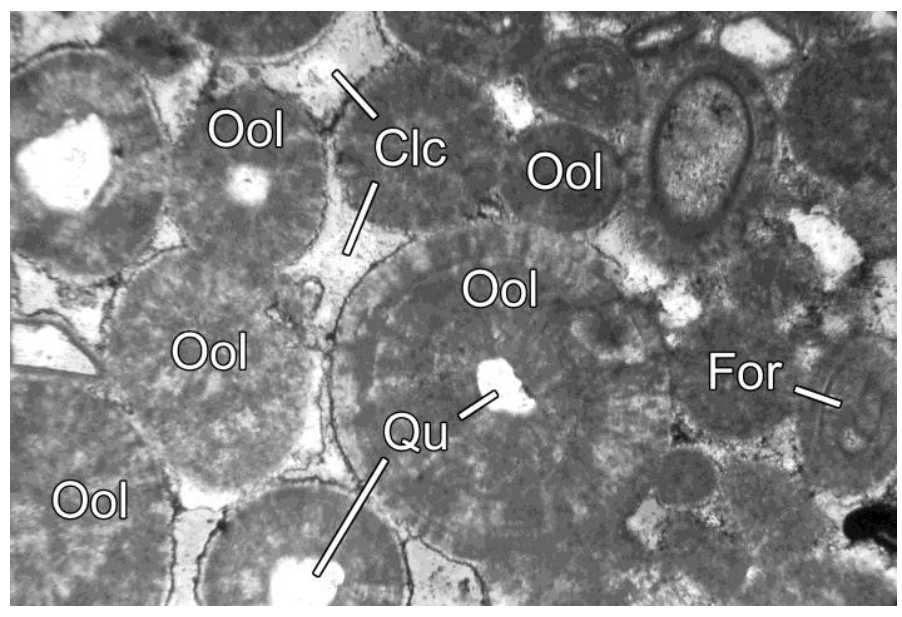

Рис. 4. Вапняк оолітовий (А-7989).

Ізометричні агрегати - ооліти (Ool), прозорі зерна в центрі оолітів - кварц (Qu), цемент поміж оолітами (світло-сірий) - кальцит (Сlc). Праворуч у центрі двох оолітів знаходяться уламки форамініфер (For).

Світло прохідне, без аналізатору, збільшення $47^{\mathrm{x}}$

3 Апостолівського району походить статуя під номером $\boldsymbol{A - 1 1 4 1 8 ,}$ виготовлена 3 істотно калішпатового біотитового граніту (рис. 5). Калієвий польовий шпат представлений мікрокліном, який разом 3 пертитами складає 50 55 \% об’єму породи. Плагіоклазу в граніті міститься значно менше - 10-15\%, слід зазначити, що мінерал є сильно змінений унаслідок серицитизації. Кварц у породі складає 25-30\%. Слюд у шліфі виявлено мало - близько $1 \%$ біотиту і менше відсотка мусковіту. Також менше одного відсотка у породі міститься рудного 
мінералу. Серед акцесоріїв у шліфі було виявлено одне зерно гранату. Структуру породи можна визначити як гіпідіоморфнозернисту.

Походження. Село Слов'янка Апостолівського району розташоване в долині p. Базавлук, у нижній течії якої проявлені граніти токівського комплексу. Рожевий граніт, з якого було виготовлено статую, в цілому схожий за петрографічними ознаками на суттєво мікроклінові граніти, що належать даному комплексу [6]. Найближче до с. Слов'янка прояви токівських гранітів знаходяться у с. Кам'янка в долині однойменної річки - притоки р. Базавлук. Безпосередньо у долині р. Базавлук граніти найближче проявлені поблизу с. Усть-Кам'янка - нижче за течією від с. Слов'янка [5]. Таким чином, досліджувану стелу, найвірогідніше, було виготовлено з місцевих порід.

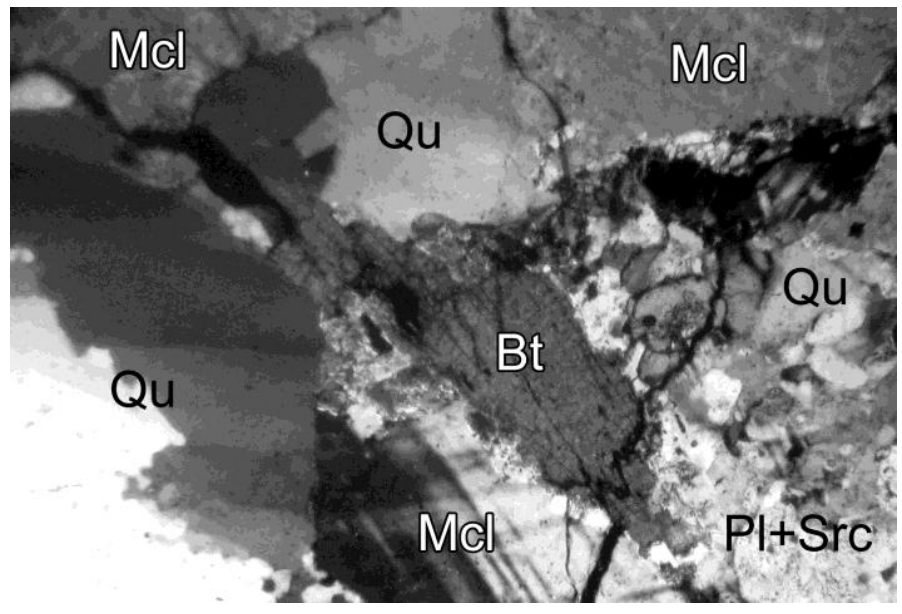

Рис. 5. Граніт біотитовий (А-11418).

Qu - кварц; Mcl - мікроклін; PI+Src - плагіоклаз серицитизований; Bt - біотит.

Світло прохідне, з аналізатором, збільшення $47^{x}$

Статую з головою у вигляді трапецієподібного виступу (A-11717) було виготовлено з біотитового граніту. Пробу для виготовлення шліфа було взято 3 суттєво кварцової ділянки. Проте, за нею можна визначити мінеральний склад породи, зокрема те, що граніт є двопольовошпатовим. При цьому мікроклін у ньому майже не проявляє гратчастого згасання і схожий на ортоклаз. Обидва польові шпати слабо серицитизовані, а калієвий польовий шпат зазнав пелітизації. У породі також зустрічаються одиничні зерна преніту, що, напевно, розвинувся по польових шпатах у результаті їх метасоматичного заміщення. У породі в істотній кількості міститься біотит, частки відсотка мусковіту, присутні одиничні агрегати рудного мінералу та близько $1 \%$ гетиту. Судячи 3 мінерального складу (значний вміст кварцу, наявність преніту) та структурних особливостей породи, вона являє собою метасоматично змінений граніт.

Походження. Згідно з музейною документацією, статуя походить 3 території Томаківського району, звідки ії було доставлено у 1983 р. Точне місце походження стели невідоме. Однак за петрографічними особливостями визначити походження іiі сировини можливо.

На території Середньопридніпровського мегаблоку істотно калішпатові граніти відносяться до порід демуринського, токівського і мокромосковського комплексів [2]. Калієвий польовий шпат у гранітах всіх зазначених комплексів 
відноситься до мікрокліну, проте, у гранітах токівського комплексу в мікрокліні відзначається підвищений вміст ортоклазового компонента. Крім того, мікроклін токівських гранітів представлений двома генераціями, у першій з яких двійникові гратки проявляються лише у частині зерен [6]. Таким чином, калієвий польовий шпат досліджуваного зразка за названими характеристиками найближче стоїть до токівських гранітів.

Другою та головною ознакою для встановлення походження даної породи $\epsilon$ наявність преніту. Даний мінерал $є$ досить рідкісним. На території УЩ у кислих породах він зустрічається лише в метасоматитах по токівських гранітах [3].

Виходячи 3 цього, сировина стели може походити з зони розповсюдження порід токівського комплексу, а саме з нижньої частини басейну р. Базавлук.

Два артефакти $з$ дослідженої колекції походять 3 с. Новокиївка Томаківського району. Це символічне зображення голови лева (A-12541) та антропоморфна cтатуя (A-12542). Сировину обох артефактів було визначено як вапняк органогенний.

У шліфі першого 3 них спостерігаються уламки черепашок морських організмів, зцементовані кристалами кальциту таблитчастої форми. Рештки черепашок забарвлені дисперсним гетитом (рис. 6).

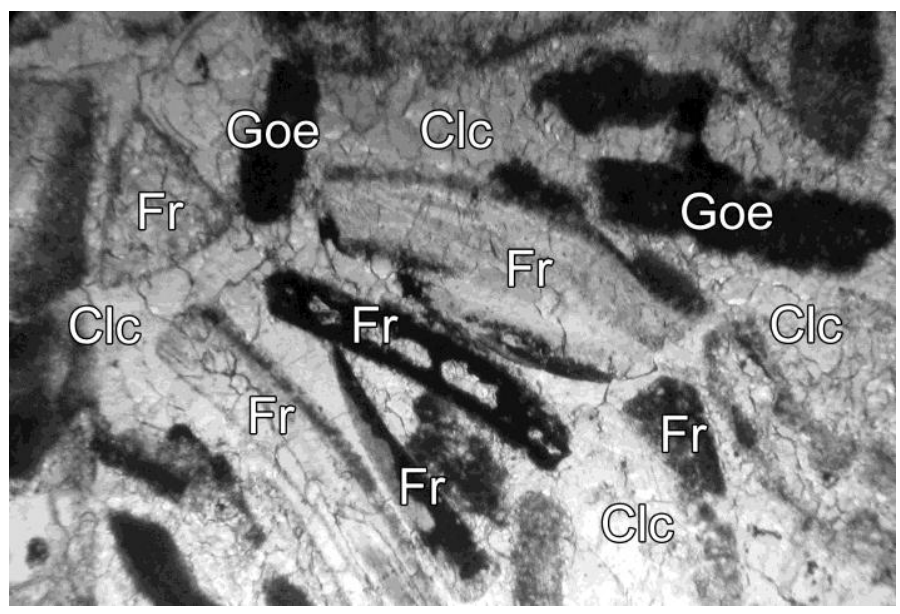

Рис. 6. Вапняк органогенний (А-12541).

Фрагменти черепашок (Fr) у кальцитовому кристалічному агрегаті (Clc). Темне - гетит (Goe). Світло прохідне, без аналізатору, збільшення $47^{\mathrm{x}}$

Вапняк другого зразка (статуї) відрізняється від сировини голови лева наявністю великої кількості пор видовженої таблитчастої та звивистої форми, що нагадують відтиски уламків черепашок. Пори у даній породі займають до $35 \%$ iі об'єму i мають довжину 0,2-2,0 мм. Деякі пори заповнені мікрозернистим кальцитом. Також сировина статуї відрізняється наявністю одиничних уламків кварцу та польових шпатів, що мають кутасту форму. Серед органічних решток у складі породи ідентифікуються спікули губок.

Походження. Органогенні вапняки досить поширені на території Томаківського району, утворюючи як незначні прояви, так і великі родовища. Серед останніх слід відзначити Грушівсько-Басанське родовище, розташоване в районі с. Новокиївка, поблизу м. Марганець. Також родовища існують північніше - 
поблизу сіл Настасівка та Мирове в долині р. Томаківка [5]. Таким чином, сировина даних зразків скіфської пластики, найімовірніше, була місцевого походження.

Антропоморфну статую під номером $\boldsymbol{A - 1 3 5 9 2}$ було виготовлено 3 біотитового двопольовошпатового граніту. Співвідношення польових шпатів у породі є практично рівним - 35-40\% мікрокліну (разом з пертитами) та 30-35\% плагіоклазу. Кварц у породі складає 25-30\%, також у граніті міститься до $2 \%$ біотиту й менше $1 \%$ мусковіту. У породі зустрічаються одиничні ділянки 3 мірмекітовою структурою і вторинний серицит, що розвинувся по плагіоклазу. Структура породи гіпідіоморфнозерниста.

Походження. Досліджувана статуя походить 3 Лівобережжя Дніпра, а саме 3 долини р. Вовча. Верхня частина басейну даної річки $є$ місцем, багатим на природні відслонення кристалічних порід. За петрографічними особливостями досліджувана порода близька до гранітів мокромосковського комплексу, які проявлені поблизу м. Запоріжжя, а також утворюють невелике тіло схожих за складом порід по p. Солона - притоці р. Вовча. Так, у гранітах мокромосковського комплексу співвідношення польових шпатів є близьким, щоправда, плагіоклаз у них трохи переважає. У мокромосковських гранітах теж присутній мірмекіт й обидві слюди, серед яких біотиту міститься набагато більше [6]. Також слід зазначити, що найближче до с. Великоолександрівка родовище гранітів знаходиться трохи вище за течією поблизу с. Преображенське [5]. Виходячи 3 цього, сировину для кам'яної стели, найімовірніше, було взято з корінних відслонень гранітів вище за течією.

Таким чином, в результаті проведеного дослідження було встановлено, що сировина наведених артефактів представлена плагіоклазовими та двопольовошпатовими гранітами, вапняками-черепашниками та оолітовим вапняком. Всі зазначені породи утворюють значні родовища та прояви на території Дніпропетровської області, крім того, досліджувані артефакти походять 3 місць розповсюдження порід, подібних їх сировині.

Висновки. Виходячи 3 отриманих даних, можна зробити висновок, що скіфським населенням Середнього Придніпров'я для виготовлення кам'яних скульптур, найімовірніше, використовувалися місцеві породи, що відслонювались в районі місць виготовлення та подальшого розташування даних артефактів. Сировиною для творів кам'яної пластики слугували архейські граніти і неогенові вапняки - породи, що утворюють найбільші родовища будівельного каміння на території Дніпропетровської області. Судячи з усього, скіфи не надавали переваги певному виду сировини, оскільки у районах розповсюдження гранітів поряд із вапняками використовувалися обидві породи.

Подальші петрографічні дослідження подібних зразків кам'яної пластики зможуть доповнити наші знання про використання гірських порід Середнього Придніпров'я у скіфський час.

Автори висловлюють щщиру вдячність керівництву ДНІМ ім. Д. І. Яворницького за наданий для дослідження матеріал, В. О. Ходасу, М. Й. Сердюк за допомогу у роботі з колекиіями музею.

\section{Бібліографічні посилання}

1. Баранов П. Н. Самоцветы Украины. В 3 т. Т. 1. Самоцветы Среднего Побужья. Агаты Рафаловского месторождения. Декоративные тектониты Среднего Приднепровья и Приазовья / П. Н. Баранов, Ю. Т. Хоменко, С. В. Цюпко [и др.]. - К.: Ювелир-пресс, 2005. - 64 с. 
2. Кореляційна хроностратиграфічна схема раннього докембрію Українського щита [пояснювальна записка] / К. Ю. Ссипчук, О. Б. Бобров, Л. М. Степанюк [та ін.]. - К.: УкрДГРІ, 2004. - 30 с.

3. Минералы Украины: краткий справочник / Н. П. Щербак, В. И. Павлишин, А. Л. Литвин [и др.]; отв. ред. Н. П. Щербак. - К.: Наук. думка, 1990. - 408 с.

4. Стратиграфія УРСР. В 11 т. Т. 10. Неоген / В. Г. Бондарчук, В. Я. Дідковский, В. Г. Куліченко [та ін.]; гол. ред. В. Г. Бондарчук. - К.: Наукова думка, 1975. $-271 \mathrm{c}$.

5. Строительные материалы Днепропетровской области: справочник / Сост. Л. М. Видергауз, Ю. Н. Алексеев, Е. Я. Биличенко [и др.] - К.: Будівельник, 1964. $291 \mathrm{c}$.

6. Щербаков И. Б. Гранитоидные формации Украинского щита / И. Б. Щербаков, К. Е. Есипчук, В. И. Орса - К.: Наукова думка, 1984. - 192 с.

Надійшла до редколегії 19.03.2014 p. 